\title{
ANALYSIS OF SERVICE QUALITY ON BUILDING LOYALTY BY USING STRUCTURAL EQUATION MODELLING METHOD (CASE STUDY IN MAJAPAHIT TRAIN)
}

\author{
Eka Arista Anggorowati \\ College of Land Transportation, Bekasi \\ E-mail: ekaariwidi@yahoo.com
}

\begin{abstract}
Train is one of the transportation modes with some special characteristics that make it possible as an effective and efficient transportation system to increase the level of service quality. Although the air conditioned economy class of Majapahit Train has been officially opened by the government, it has not been able to fulfill the people's need. It is proved with the decrease of number of passenger, and the increase of critics related to the service quality. This research aims to analyze the principal elements and the effect of service qualities towards the customer's loyalty. The research was conducted through survey on the Majapahit Train users consisting of 200 respondents. The used sampling technique was non probability sampling with purposive sampling method. It applied Structural Equation Modelling (SEM) in which the previous test was the classical assumptions. Based on the calculations, it is indicated that the variables of service quality in customer satisfaction and loyalty is significant. The principal elements that influence satisfaction and loyalty are the operational schedule, the rolling stock condition, station's comfort and security, safety, ticket price, and how the passengers enjoy the travelling. Adjusted R square of 0.82 shows that 82 percent of consumer' loyalty can give impact on service quality and customer satisfaction.
\end{abstract}

Keywords: service quality, consumer satisfaction, loyalty, Structural Equation Modelling (SEM)

\section{INTRODUCTION}

In order to achieve an ideal transportation mode, service quality of the train should be enhanced. One of the improvements can be seen in the new air conditioned (AC) economy class of Majapahit Train which operated in 2012 to replace the Matarmaja business class. However, the government intention on increasing costumers' satisfaction by providing air conditioned facility on economy class train did not receive positive response. At this time, the service quality becomes an important issue on transportation service management which has an impact on satisfaction and loyalty of the customers. The expectation of train service provider in fulfilling what people need was not aligned with the customers' appraisal. The performance of the service provider is assessed by the society. Some factors that can affect customer's loyalty are the satisfaction level and the quality of the given service. The satisfaction factor can be reflected from the affordability of the ticket price and its compatibility with the existing facilities. The service quality factor can be seen from the reliability level, assurance, tangibles, empathy and responsiveness.

The variables in this research cannot be directly measured so that it needs constructing by other measurable indicators. This research attempts to develop the causal relation as Bollen (1989) proposed one of the method namely the Structural Equation Modelling (SEM). Structural Equation Modelling includes the measurement model and the structural model. The structural model specifies the causal relation between the latent variables, while the measured model specifies the relation between the indicators with the latent variables. This research intends to find out the main relation between service quality and customer satisfaction.

\section{SERVICE QUALITY ANALYSIS}

\subsection{Marketing}

According to Kotler (2000), marketing is a social process where individuals and organization obtain what they need and what they want through creating, offering, and freely exchanging valuable service and product with other parties.

\subsection{Service Quality}

The definition of service is every action or activity which can be offered by a party to other party, which is basically intangible and would not affect any ownership (Kotler \& Gary, 2001). Quality can be interpreted as a measurement on how good the given service and how suitable it is to the consumer's expectations, then giving a good service is to conform to consumer's expectations. It is one of the success factors to enhance tight competition. A good service quality is the orientation of the entire human resources in a company for the satisfaction of the customer. Parasuraman, et.al. $(1985 ; 1988)$ describes the five 
indicators or dimensions of the service quality: reliability, tangibles (physical facilities), responsiveness, assurance (security and safety), and empathy. Parasuraman, et.al. (1991) revealed that reliability is basically related to the result of the services, tangibles, responsiveness, assurance and warranty, while empathy is related to the process on the delivery of the service.

\subsection{Satisfaction}

Satisfaction is generally a feelings of pleasure or disappointment resulted by comparing product performance (outcome) to his or her expectations. Kotler (2000) stated that there are three important points to build the customer satisfaction, i.e. quality, service, and value. Customer satisfaction should be identified by a company in order to understand the performance of the company from the customers' point of view.

\subsection{Loyalty}

Boulding, et al. (1993), as recited by Darsono (2008) revealed that brand loyalty is resulted from the influence of accumulated satisfaction/dissatisfaction towards service and product quality. The costumers' loyalty on a brand highly depends on the ability in handling the factors.

\section{RESEARCH METHODOLOGY}

\subsection{Data Sources}

This research is conducted by using secondary data and primary data. Secondary data consists of passenger number, operational area contribution data, traffic capacity data, and train traffic map obtained from PT. KAI. Primary data are obtained from interview survey and questionnaire distribution to respondents who qualify the validity criteria and also have good reliability.

\subsection{Research Design and Steps}

The structural equation model and research design are described in Figure 1 and Figure 2. LISREL Software Version 8.80 is used to analyze the data with the steps are explained as follows:

a) Formulate the model

b) Make input matrix by saving the data in SPSS format then import it to PRELIS data in the "file.cov" form

c) Specify model parameters based on correlation matrix result

d) Calculate the construct reliability and variance extracted values

e) Evaluation on the model feasibility is generated based on fitting test using GFI, CFI, AGFI and RMSEA models.

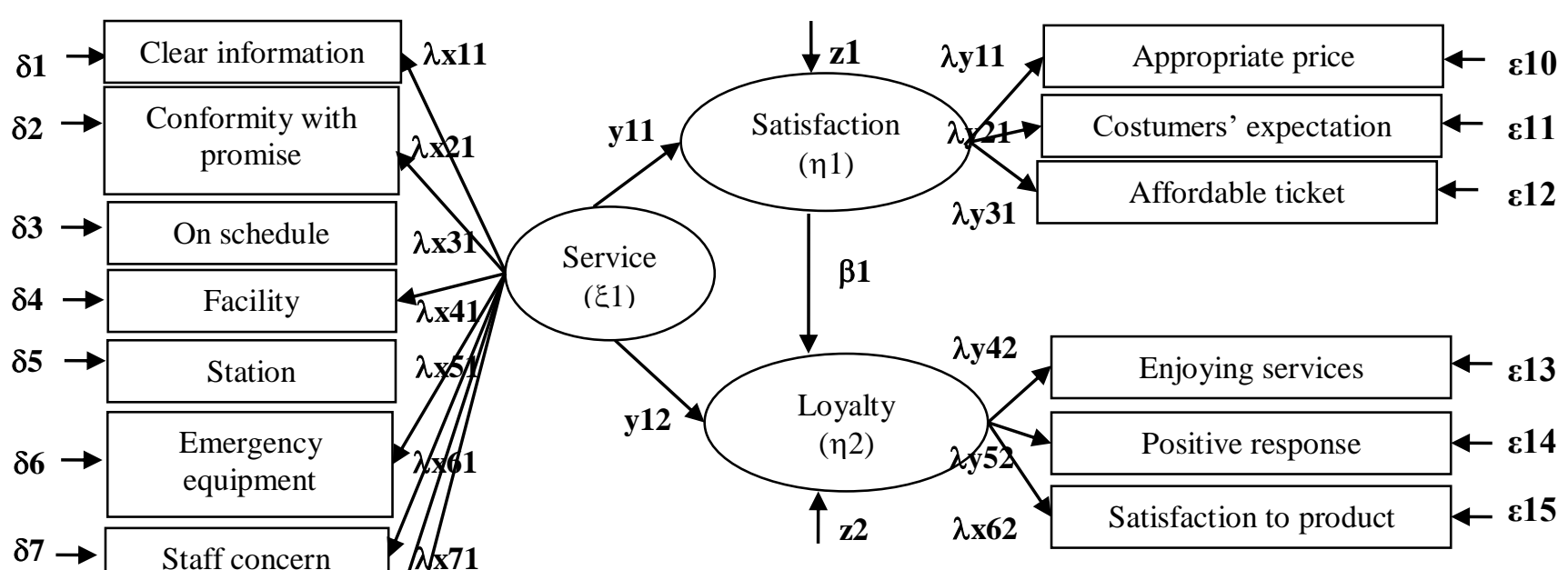




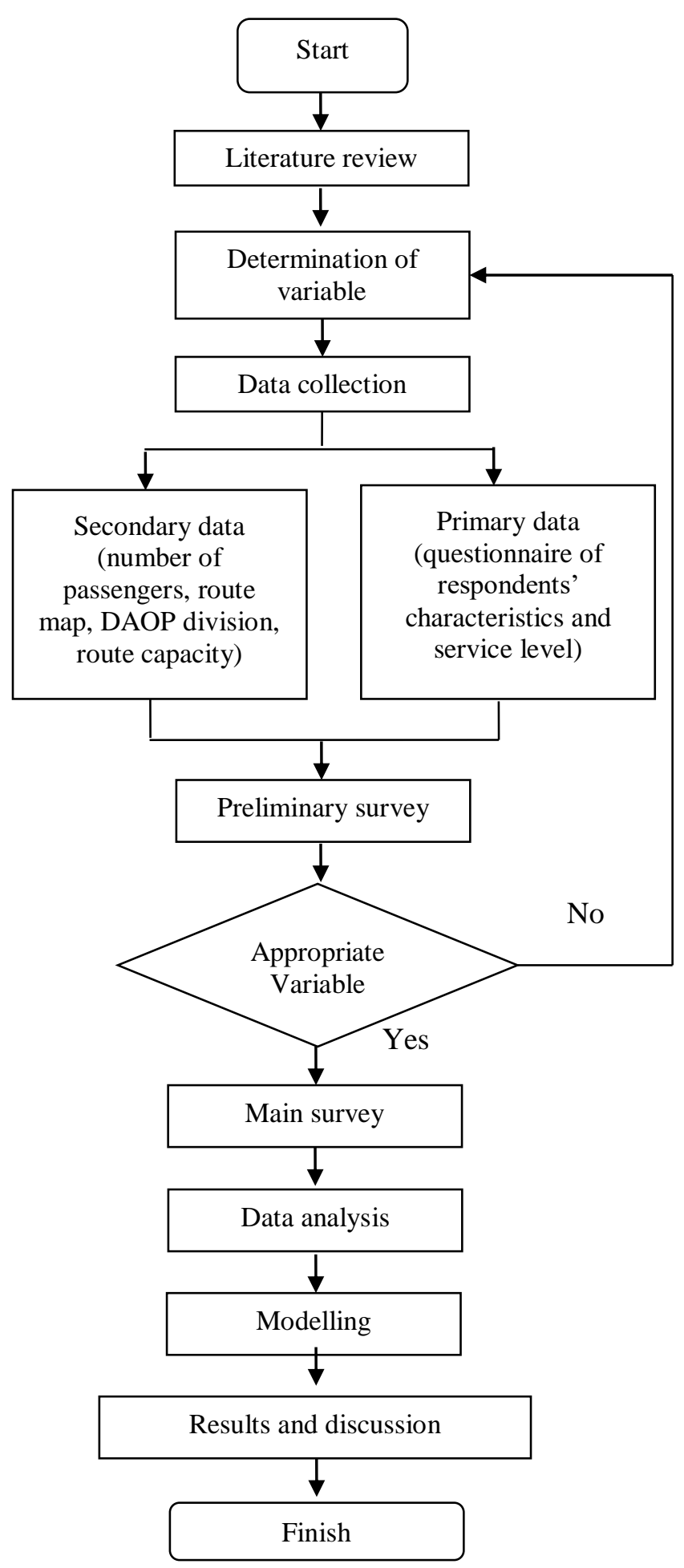

Figure 2. Research design

\section{RESULTS AND DISCUSSION}

\subsection{Research Data}

General perception of respondents about service, satisfaction, and loyalty are shown in Table 1. Perception index of the respondents (Ferdinand, 2006) is as follows:

$40.00-93.33=$ Low; $93.34-146.67=$ Moderate; and $146.68-200=$ High
The results indicated that the measured index value was 153.67. According to the respondent's perception, the service quality highly affects the satisfaction level building customer loyalty.

\subsection{Classical Assumptions Test}

Classical assumptions test was analyzed by using data normality test and data multi co-linearity test. From the P-Plot diagram (Figure 3) and the reliability test result (Table 2), it was found that the data was normal with VIF value less than 5, so that the data was considered feasible to be used for advanced analysis using the SEM method.

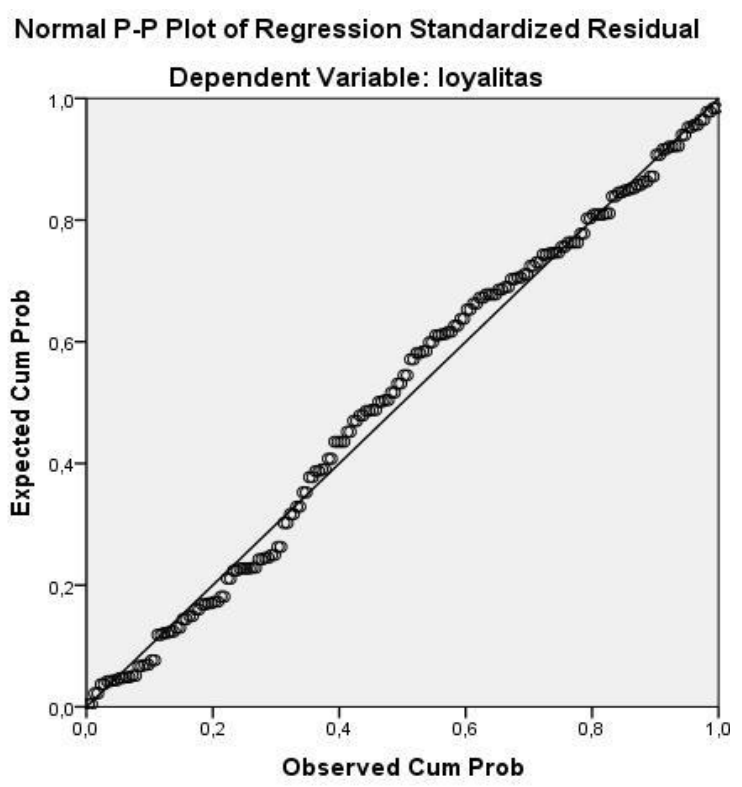

Figure 3. P-Plot diagram.

\subsection{Results of Structural Equation Modelling (SEM)}

Based on Figure 4, it can be seen that the main factors indicating that the train service customers expect on schedule condition, facility, emergency equipment, comfort, safety, conformity with the expectation, ticket affordability, enjoying the service, and the satisfaction from offered product. It can be seen that the loyalty level was affected by 1.44 satisfaction and 0.2 service. On the SEM, it also calculated the structural error value between the exogenous and endogenous latent variable which was 3.74 between satisfaction and service, and 0.04 between the service and loyalty, the closer to 0 the structural model can be measured better. Furthermore, the parameter value between the latent variable and its indicator can be measured with 0.52 schedule accuracy indicator. The higher parameter value, the better indicator gained. The error value of each indicator was also calculated by using SEM. 
Table 1. Result of Majapahit Train passengers' perception on service, quality, and loyalty

\begin{tabular}{|c|c|c|c|c|c|c|c|}
\hline \multirow[b]{2}{*}{ No. } & \multirow[b]{2}{*}{ Question point } & \multicolumn{5}{|c|}{ Measurement scale } & \multirow{2}{*}{$\begin{array}{l}\text { Index } \\
\text { value }\end{array}$} \\
\hline & & $\begin{array}{l}\text { Not } \\
\text { agree }\end{array}$ & $\begin{array}{l}\text { Less } \\
\text { agree }\end{array}$ & $\begin{array}{l}\text { Quite } \\
\text { agree }\end{array}$ & Agree & $\begin{array}{l}\text { Very } \\
\text { agree }\end{array}$ & \\
\hline $\mathrm{X} 1$ & Information clarity and train staff service speed & 9 & 21 & 49 & 59 & 62 & 148.8 \\
\hline $\mathrm{X} 2$ & Train operational schedule accuracy & 7 & 19 & 46 & 64 & 64 & 151.8 \\
\hline X3 & Compatibility with given promises & 5 & 24 & 68 & 58 & 45 & 142.8 \\
\hline $\mathrm{X} 4$ & Train facility condition (seat, toilet, AC, doorway) & 0 & 16 & 49 & 61 & 74 & 158.6 \\
\hline $\mathrm{X} 5$ & $\begin{array}{l}\text { Station condition and cleanliness (seat, toilet, baggage, AC, } \\
\text { door condition, lighting, health care, ATM) }\end{array}$ & 0 & 14 & 53 & 65 & 68 & 157.4 \\
\hline X6 & $\begin{array}{l}\text { Emergency equipment (first aid kit, fire extinguisher, } \\
\text { emergency brake instruction guide) }\end{array}$ & 0 & 21 & 48 & 63 & 68 & 155.6 \\
\hline $\mathrm{X} 7$ & Employee awareness in handling the service & 0 & 23 & 58 & 68 & 51 & 149.4 \\
\hline $\mathrm{X} 8$ & Comfort and safety in station and also in train & 6 & 19 & 50 & 64 & 61 & 151 \\
\hline X9 & Train safety guarantee & 0 & 13 & 42 & 68 & 77 & 161.8 \\
\hline $\mathrm{X} 10$ & Ticket price affordability & 0 & 21 & 49 & 64 & 66 & 155 \\
\hline $\mathrm{X} 11$ & Train meet customer expectation & 11 & 15 & 53 & 54 & 67 & 150.2 \\
\hline $\mathrm{X} 12$ & Tariff compatibility with train facility & 9 & 13 & 47 & 59 & 72 & 154.4 \\
\hline $\mathrm{X} 13$ & Passenger enjoys the service & 0 & 13 & 74 & 83 & 30 & 146 \\
\hline $\mathrm{X} 14$ & Mention positive points and recommend to friends & 0 & 16 & 76 & 72 & 36 & 145.6 \\
\hline $\mathrm{X} 15$ & Satisfaction on offered product & 0 & 8 & 44 & 41 & 107 & 169.4 \\
\hline \multicolumn{2}{|c|}{ Total } & 47 & 256 & 806 & 943 & 948 & 461 \\
\hline \multicolumn{2}{|c|}{ Average } & 0 & 85.33 & 268.67 & 314.33 & 316.00 & 153.67 \\
\hline
\end{tabular}

Table 2. Coefficient ${ }^{\mathrm{a}}$ reliability test result

\begin{tabular}{|c|c|c|c|c|c|c|c|c|}
\hline \multirow{2}{*}{\multicolumn{2}{|c|}{ Model }} & \multicolumn{2}{|c|}{ Unstandardized coefficients } & \multirow{2}{*}{$\begin{array}{l}\text { Standardized coefficients } \\
\text { Beta }\end{array}$} & \multirow{2}{*}{$\mathrm{t}$} & \multirow{2}{*}{ Sig. } & \multicolumn{2}{|c|}{ Co-linearity statistics } \\
\hline & & $\mathrm{B}$ & Std. Error & & & & Tolerance & VIF \\
\hline \multirow{3}{*}{1} & (Constant) & 5.832 & 1.511 & & 3.860 & 0.000 & & \\
\hline & Service & 0.121 & 0.059 & 0.152 & 2.070 & 0.040 & 0.904 & 1.106 \\
\hline & Satisfaction & 0.114 & 0.081 & 0.103 & 1.412 & 0.160 & 0.704 & 3.103 \\
\hline
\end{tabular}

a: Loyalty (dependent variable)

\subsection{The Goodness of Fit Test}

Results of the goodness of fit test and reliability test show that model variable meet the requirements as can be seen in Table 3 and Table 4, so that the model can be accepted. Structural model and the size of influence that were obtained from the analysis result are as follows:

Satisfaction $=0.9824 \times$ Service

Loyalty $=1.1440 \times$ Satisfaction +0.2054 x Service

Structural model fitness can be seen from $\mathrm{R}^{2}$ value of the adjusted structural equation.

Loyalty $=$ Service Satisfaction $=0.8246$

This statement means that the above structural model could explain $82 \%$ of the actual condition on the field (see Figure 4).
Table 3. Goodness of fit test result

\begin{tabular}{|c|c|c|c|}
\hline Goodness of fit & t Cut off value & Analysis result & $\begin{array}{l}\text { Model } \\
\text { evaluation }\end{array}$ \\
\hline RMSEA & $<0.08$ & 0.01879 & Good \\
\hline GFI & $>0.90$ & 0.9528 & Good \\
\hline AGFI & $>0.90$ & 0.9115 & Good \\
\hline CFI & $>0.95$ & 0.8190 & Marginal \\
\hline
\end{tabular}

Table 4. Model reliability test

\begin{tabular}{lll}
\hline Latent variable & CR & Reliability conclusion \\
\hline Service Quality & 0.9464 & Good \\
Satisfaction & 0.7046 & Good \\
Customer Loyalty & 0.7989 & Good \\
\hline
\end{tabular}

\section{HYPOTHESIS TEST}

The test of the above hypothesis was described in Figure 5. The calculated value was bigger than critical ratio value, so the null hypothesis was rejected which means that the quality of service and passengers' satisfaction influence the loyalty. 


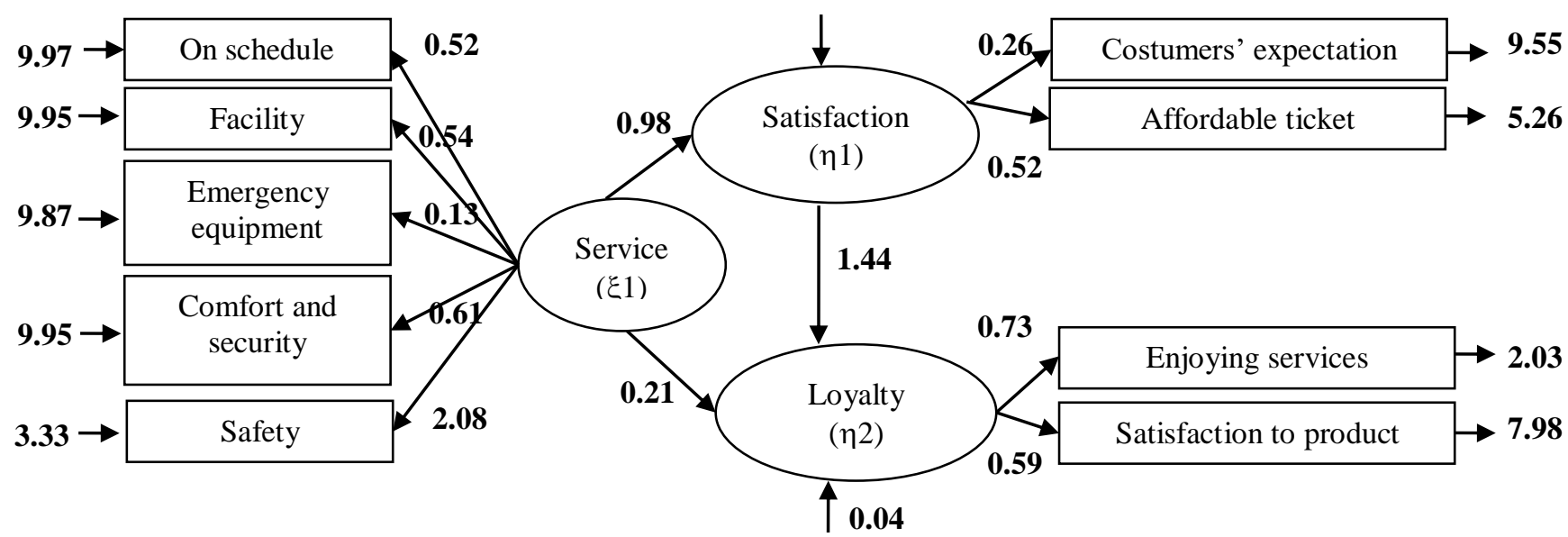

Figure 4. Structural model parameter prediction result with SEM.

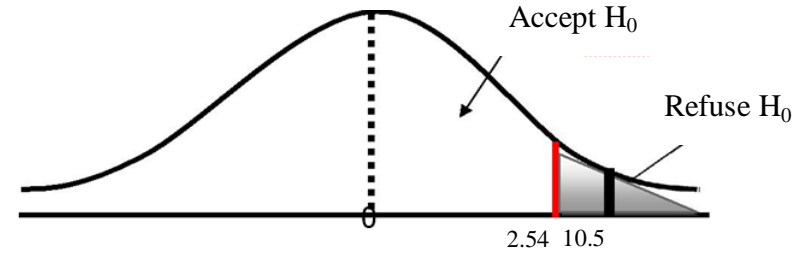

Figure 5. Two tailed test

\section{CONCLUSIONS}

Based on the results, some conclusions which can be drawn are as follows:

a) General perception of respondents showed that the given service quality affecting the satisfaction is higher, thus this matter plays an important role in increasing the loyalty of the train consumer.

b) The main indicators making the satisfaction level become the most influenced in collecting the customer's loyalty are on schedule condition, train facilities, comfort and safety factor in both station and train, train safety guarantee, customer's pleasure on train service, and satisfaction to the offered product.

c) From the analysis result, it can be found that the equation of service quality, satisfaction, and loyalty is as follows:

Loyalty $=1.440 \times$ Satisfaction $+0.2054 \times$ Service

d) If the quality of the service quality increases, consumers' satisfaction also increases, therefore it will influence the increase of consumer's loyalty.

e) There is a relation between service quality and satisfaction. This was shown in the $\mathrm{R}^{2}$ value 0.8246 , which means that $82 \%$ of service quality affected customer satisfaction level which may build the customer loyalty.

\section{RECOMMENDATIONS}

Several treatments can be applied to enhance the train system are as follows:

a) By changing single track to double track, the application of ATP (Automatic Train Protection) system may reduce waiting time and traveling time in previous station before crossing with train.

b) In order to anticipate people's vandalism which can damage public facilities, window glass material needs changing. Materials considered good because of its strength and flexible trait for replacing the current one are polycarbonate and acrylic rayban.

c) GPS (Global Positioning System) is required in order to ease train travel surveillance and investigation to keep data safe.

d) ATP system application can anticipate accident between trains since it can work automatically if the train operator breaks the signal.

e) Based on the questionnaire, in order to increase customer loyalty, several stations that have quite high demand need to be visited. Enhancing the accessibility from and to station is also important to facilitate the train users.

\section{REFERENCES}

Bollen, K. A., 1989. A New Incremental Fit Index for General Structural Equation Models. Sociological Methods \& Research, pp. 303-316. 
Boulding, W., Kalra, A., Staelin, R. \& Zeithaml, V., 1993. A Dynamic Process Model of Service Quality: From Expectation to Behavioral Intentions. Journal of Marketing Research.

Darsono, L. I., 2008. Hubungan Perceived Service Quality dan Loyalitas: Peran Trust dan Satisfaction sebagai Mediator [Relation between Perceived Service Quality and Loyalty: Trust Role and Satisfaction as Mediator]. Surabaya, UKWMS.

Ferdinand, A., 2006. Structural Equation Modelling Dalam Penelitian Manajemen [Structural Equation Modelling in Management Study]. 4 ed. Semarang: Publisher of Diponegoro University.

Kotler, P., 2000. Marketing Management, the Millennium Edition. New Jersey: Prentice Hall.

Kotler, P. \& Gary, A., 2001. Principles of Marketing. Jakarta: Erlangga.
Parasuraman, A., Zeithaml, V. A. \& Berry, L. L., 1985. A Conceptual Model of Service Quality and Its Implication. Journal of Marketing, pp. 41-50.

Parasuraman, A., Zeithaml, V. A. \& Berry, L. L., 1988. SERVQUAL: A Multi-Item Scale for Measuring Consumer Perceptions of the Service Quality. Journal of Retailing, pp. 12- 40.

Parasuraman, A., Zeithaml, V. A. \& Berry, L. L., 1991. Refinement and Reassessment of the SERVQUAL Scale. Journal of Retailing, pp. 420450. 